\title{
La investigación sobre los judíos del Reino de Aragón hoy *
}

\author{
Asunción Blasco Martínez **
}

\section{INTRODUCCIÓN}

Hace ahora dos años, en el "l Col-loqui d'Història de la Corona d'Aragó» celebrado en Lérida en 1989, esbocé una visión sistemática de la historiografía sobre los judíos del reino de Aragón desde 1918, año en que se publicó el estudio de Serrano, el primer trabajo serio y bien documentado sobre historia interna de los judíos de ese Reino. Para no incidir en lo que entonces dije, remito al mencionado estudio, que en general ${ }^{1}$ suscribo, sin perjuicio de matizar alguna de mis afirmaciones de entonces.

Trataré ahora de analizar algunos aspectos de lo que se acaba de hacer o se está haciendo sobre la historia de los judíos del reino de Aragón y, sobre todo, de lo que todavía queda por realizar en un tema que en estos momentos está de actualidad. Tanto es así, que en el corto período transcurrido desde 1989 el número de publicaciones sobre los judíos hispánicos se ha incrementando considerablemente: quizá porque en el presente año se rememora el sexto centenario de los alborotos de 1391 y porque en el ya muy próximo 1992, amén de otras muchas conmemoraciones y aniversarios se cumplen los quinientos años de la expulsión de los judíos de las Coronas de Castilla y de Aragón.

\footnotetext{
* En la realización de este trabajo me he beneficiado de la ayuda del Proyecto $n .^{\circ}$ PB900449-C02-02 de la Dirección General de Investigación Científica y Técnica (DGICYT) del Ministerio de Educación y Ciencia.

** Dpto. de Historia Medieval, C. y T. Historiográficas. Universidad de Zaragoza.

- Salvo alguna pequeña rectificación, que no me ha sido posible realizar por no haber tenido acceso a las pruebas de imprenta. Véase Blasco MARTínEZ, Asunción: «Los judíos del reino de Aragón: Balance de los estudios realizados y perspectivas» en jer Colloqui d'Història dels jueus a la Corona d'Aragó (Institut d'Estudis Ilerdencs, Lleida 1991), págs. 13-97.
} 


\section{EL PASADO RECIENTE: LOS ÚlTIMOS TRES AÑOS}

Empezaré por el estado de la cuestión de lo que, según Romano, algunos consideran "subproducto" de la historia medieval ${ }^{2}$. Es cierto que muchos de los que nos dedicamos a la historia de los judíos (hebraístas, medievalistas y aficionados de procedencia diversa ${ }^{3}$ ) nos circunscribimos a ese ámbito de la investigación ante la necesidad, incuestionada e incuestionable, de realizar análisis y monografías que posibiliten posteriores trabajos de síntesis. Pero no es menos cierto que esa tarea viene a paliar el abandono por parte de algunos medievalistas — por fortuna no son todos ${ }^{4}$ - del estudio de las minorías confesionales, no por desinterés sino en aras de la necesidad de especialización que la Historia exige, en ese o en cualquier otro campo.

En los últimos años, se ha incrementado la producción y la nómina de los investigadores especializados en el tema. Además de los aragoneses de nacimiento (Federico Balaguer ${ }^{5}$, Miguel Angel Motis ${ }^{6}$ ), o de adopción (Encarnación Marín ${ }^{7}$ ), entre los que me cuento ${ }^{8}$, dedicados de forma casi exclusiva a investigar en el asunto que nos ocupa, hay otros que eventualmente han abordado estudios monográficos sobre la historia

2 Romano, David, Perspectivas de la Historia judía de la Corona de Aragón, ponencia presentada en este mismo Encuentro.

3 La razón de esta mescolanza estriba en que todavía no existe en nuestro país la tan traída y llevada cátedra de Historia de los judíos.

4 Entre otros, son conocidos por sus aportaciones Eloy Benito, Enrique Cantera, Juan Carrasco, Antonio Collantes de Terán, José Hinojosa, Miguel Ángel Ladero, Emilio Mitre, José Monsalvo, Isabel Montes, Leopoldo Piles, Alvaro Santamaría, José Ángel Sesma, Luis Suárez, Juan Torres Fontes y Julio Valdeón.

5 Federico Balaguer Sánchez, uno de los pioneros aragoneses en la investigación de los judios de Alto Aragón, prosigue sus tareas investigadoras de las que suele dar cuenta en la revista Sefarad y en otras de carácter más local, como Argensola.

6 La investigación de Miguel Ángel Motis Dolader se centra en la segunda mitad del siglo $x V$, y más concretamente en torno a la expulsión de los judíos. Este autor maneja sobre todo fuentes locales (municipios y notariales) de distintos lugares del antiguo Reino, que ha dado a conocer en colecciones de regesta y documentos. Sus escapadas a otras épocas y asuntos son más bien divulgativas, y en esos casos la selección bibliográfica (cuando la hay) no siempre es selectiva.

7 Los estudios de Encarnación Marín Padilla se basan fundamentalmente en procesos inquisitoriales contra judaizantes aragoneses, llevados a cabo por el Tribunal del Santo Oficio de Zaragoza, y en fuentes notariales (sobre todo del siglo xv) de esta ciudad y de otros lugares de su provincia: Épila, Calatayud y La Almunia de Doña Godina. Es de resaltar la aportación masiva de datos documentales en todos sus artículos, que preferentemente se publican en la revista Sefarad.

8 Desde hace años mis estudios se han centrado en la historia de los judíos de Aragón, en general, y de los de Zaragoza, en particular, en los siglos XIV y XV, y sobre todo en el período comprendido entre los años 1316-1415. La base de esta investigación la constituyen las fuentes oficiales (registros de Cancillería del Archivo de la Corona de Aragón y fondo del Real Patri- 
de los judios de Aragón: es el caso de Ángel Alcalá ${ }^{9}$, Manuel Gómez Valenzuela ${ }^{10}$, Pilar Pérez Viñuales ${ }^{11}$, Angel Sesma Muñoz ${ }^{12}$

No faltan los investigadores de otras comunidades autónomas, entre los que destaca Romano, buen conocedor de la historia de los judíos de la Corona de Aragón ${ }^{13}$, de Castilla ${ }^{14}$ y de los Estados hispánicos en general ${ }^{15}$, según ha venido demostrando a lo largo de su larga trayectoria investigadora y muy especialmente en estos últimos años.

monio conservado en ese archivo) y locales, especialmente las notariales pues no existe documentación municipal de la capital del Reino anterior al siglo xv. Recientemente he extendido mi investigación al estudio de aspectos concretos del siglo xv: los judíos francos y las fuentes escritas relativas a la expulsión.

כ Angel Alcalá es experto en Inquisición y está especialmente preocupado por la historia de los judios de Aragón (AlcalÁ, Ángel, "La disputa de Tortosa de 1414 -entre dos alcañizanos- y comienzo del fin de la judería aragonesa», Primera Semana Sefardí (Zaragoza, 9-14 de mayo de 1991).

10 Gómez Valenzuela, Manuel, «La actividad mercantil de los judíos de Jaca y Huesca en el Alto Valle del Gallego (1426-1487)», Argensola (Huesca), 101 (1988), págs. 97-155.

11 Perez viÑuales, Pilar, «Judíos en Alagón», Destierros Aragoneses, Institución Fernando el Católico (Zaragoza 1988), págs. 127-134 y Alagón en la Edad Media, Zaragoza, Institución Fernando el Católico. 1988, págs. 42-48.

12 Sesma Muñoz, José Ángel; "Violencia institucionalizada: el establecimiento de la Inquisición por los Reyes Católicos en la Corona de Aragón", Aragón en la Edad Media (Zaragoza), 8 (1989), págs. 659-673, realizado sobre el repertorio publicado por este mismo autor con el título: El establecimiento de la Inquisición en Aragón (1484-1486). Documentos para su estudio, I. Zaragoza, Fernando el Católico, 1987.

${ }_{13}$ Amén de los estudios reseñados en Blasco, Los judios del reino de Aragón: Balance de los estudios realizados y perspectivas (cit. en la nota 1), véase RomANO, David; "Los judíos de la Corona de Aragón en la Edad Media». España, Al-Andalus, Sefarad: Síntesis y nuevas perspectivas (Universidad de Salamanca, Salamanca, 1988), págs. 153-168; Els jueus de la Corona dÁragó en temps de Pere el Ceremoniós (1336-1387), en Pere el Ceremoniós i la seva època (Consell Superior d'investigacions Científiques/Institució Milà i Fontanals, Barcelona 1989), págs. 113-131.

14 Romano, David; Fuentes mo castellanas para la historia de los judíos de Castilla (Ejemplos de los siglos xill y xiv, en el Congreso "Proyección histórica de España en sus tres culturas», Junta de Castilla y León. Valladolid 1993. Vol. III, págs, 169-176; «Judíos hispánicos en los siglos IV-1X, en De la Antigüedad al Medioevo (siglos $\mathrm{N}$ al vili), Ill Congreso de Estudios Medievales, León 23-27.9.1991 (en prensa).

15 Romano, David; "Habitats urbains des juifs hispaniques", en Les sociétés urbaines dans la France meridionale et la Péninsule Ibérique au Moyen Age, Pau 21-24.9.1988 (París 1991); "Los judíos y el campo en los estados hispánicos", en Proceedings of the Tenth World Congress of Jewish Studies, Division B, vol. II: The History of the Jewish People. (Jerusalem 1990), págs. 135-142; "Demografía judía en la Corona de Aragón: planteo sistemático para determinar cifras de población», en Spanish Jewry and its Dispersion; Its Influence on the History of Spain and on Jewish History, aneja al 17 th International Congress of Storical Sciences. Madrid 27.8.1990; «Judíos hispánicos y mundo rural», Sefarad, Ll (1991), págs. 352-367; De historia judía hispánica, Universitat de Barcelona, 1991: Ragos de la minoria judía en la Corona de Aragón, Congreso "Judíos y conversos en la historia». Rivadavia, 14-18.10.1991; "Judíos hispánicos: coexistencia, tolerancia, marginación (1391-1492: de los alborotos a la expulsión)", en La Península Ibérica en la Era de los descubrimientos, lli Jornadas hispano-portuguesas de Historia Medieval. Sevilla 25.11.-1.12.1991 (en curso de publicación). 
Desde hace tiempo, la historia de los judíos españoles, en general, y de los aragoneses, en particular, ha interesado a estudiosos de diversos países: la escuela que en su día creara el profesor Fritz Baer, en Jerusalén, sigue hoy en plena actividad, según los demuestran los estudios realizados en fecha reciente por Yom Tov Assis ${ }^{16}$. Con menor incidencia, aunque con idéntica profundidad, han investigado sobre el pasado judío de Aragón -y continúan haciéndolo hoy- Eleazar Gutwirth, de la Universidad de Tel Aviv, siempre preocupado por el mundo de las mentalidades ${ }^{17}$, y Moisés Orfali, de la Bar llan, especialmente interesado por la controversia cristianojudía y por el estudio de las fuentes rabínicas ${ }^{18}$. También Elena Lourie, de la Universidad Ben Gurion de Negev, ha dedicado diversos trabajos a esclarecer las relaciones entre judíos y musulmanes de Aragón ${ }^{19}$. Desde el país vecino, Beatriz Leroy, más interesada en los asuntos navarros, no ha desaprovechado la ocasión que los documentos le brindan de acercarse a analizar los contactos, a veces notables, entre las juderías de Navarra y Aragón ${ }^{20}$.

No podemos olvidar a los investigadores del otro lado del Atlántico, como David Nirenberg, que en sus largas y apretadas horas de trabajo en el Archivo de la Corona de Aragón encontró, además de los datos que buscaba para su tesis doctoral sobre las relaciones entre mudéjares y judíos aragoneses a comienzos del siglo xIV, algún documento suelto de indudable interés, como el que hace alusión a Ceti, «rabissa» de la Sinagoga mayor de Zaragoza en tiempos de Jaime II ${ }^{21}$.

Sería injusto que en esta relación de estudiosos del judaísmo de Aragón no estuvieran presentes los medievalistas aragoneses que ocasionalmente y de refilón han estudiado el tema con excelentes resultados:

16 Me refiero a ellos más adelante, Véanse las notas 31 y 80.

17 GuTwIRTH, Eleazar, «Social criticism in Bonafed's invective and its historical background", Sefarad (Madrid), XLV (1985), págs. 23-54, y también «Hispano-Jewish Attitudes to the Moors in the Fifteenth Century», Sefarad, XLIX (1989), págs. 237-262.

18 Orfal, Moisés; Datos sobre las aljamas del reino de Aragón en los Responsa Rabínica, comunicación presentada al "l. er Col.loqui de Història dels jueus a la Corona d'Aragó», Lérida 29-30.11.1989, aunque no se ha publicado; y "La polémica interreligiosa y las conversiones", Congreso internacional: La Cultura de los judios de España. Tel-Aviv 1-4.7.1991.

${ }_{19}$ Interesa especialmente la recopilación de diez de sus artículos que bajo el título Crusade and Colonisation ha aparecido recientemente en la Collected Series: CS317 (LourIE, Elena, Crusade and Colonisation. Muslims, Christians and Jews under Crown of Aragon. London, Variorum Reprints, 1990).

20 LEROY, Beátrice, "Les relations des juifs de Navarre et des juifs de la couronne d'Aragon», en ${ }^{e r}$ Col.loqui d'Historia dels jueus a la Corona d'Aragó. Lleida, Institut d'Estudis Ilerdencs, 1991, págs. 157-164.

21 NiREnberG, David, "A Female Rabbi in Fourteenth Century Zaragoza?", Sefarad, LI (1991), págs. 179-182. 
estoy pensando, por ejemplo, en Carlos Laliena Corbera ${ }^{22}$ y en M. ${ }^{a}$ Luisa Ledesma quien, sin abandonar la investigación sobre los mudéjares aragoneses iniciada hace ya varios años, se ha preocupado de la repercusión que el problema judío tuvo en las comunidades musulmanas del Reino ${ }^{23}$.

\subsection{Fuentes}

No abordaré en profundidad la heurística y la bibliografía para no colisionar con otros colegas ${ }^{24}$. No obstante, para completar cuanto dije al respecto en $1989^{25}$, considero conveniente señalar que en los últimos tres años se ha profundizado en el conocimiento de las crónicas ${ }^{26}$ y se ha continuado la publicación de fuentes documentales cristianas (oficiales y locales), labor que considero de especial interés cuando se trata de documentos, no de regesta. Por lo que se refiere a las fuentes oficiales de carácter nacional o general, cabe destacar los documentos publicados por Conde acerca de la expulsión de los judíos de la Corona de Aragón ${ }^{27}$. De carácter más local son unas ordenaciones de la alcabala de la aljama de Huesca del año 1389, publicadas por Motis, y la colección de regesta y documentos sobre la expulsión de los judíos de Calatayud, extraídos por el citado compilador de archivos privados (notariales) y de la bibliografía ${ }^{28}$. En la públicación de fuentes para la historia de los judíos de la Corona de Aragón, es preciso elogiar aquí la valiosa labor que desde

22 Laliena Corbera, Carlos, «Orígenes y extinción de una aljama judaica: Aicañiz, 1280 1414", Destierros Aragoneses, vol. I: Judios y moriscos. Zaragoza, Institución Fernando el Católico, 1988, págs. 115-126.

${ }^{23}$ Ledesma Rubio, M. ${ }^{a}$ Luisa, "La incidencia del problema judío en las comunidades mudéjares en Aragón», en Congreso Internacional "La Península Ibérica en la Era de los Descubrimientos, 1391-1492, III Jornadas hispano-portuguesas de Historia Medieval». Sevilla, 25.11. 1.12.1991.

24 David Romano nos ha dado una visión general del tema, mientras que Yom Tov Assis se ocupará de los Responsa. Por su parte, Miguel Ángel Motis trató recientemente de ello (MoTIS DOLADER, Miguel Ángel, «Los judíos: fuentes para su estudio y metodología de investigación», VII Jornadas, Metodología de la Investigación científica sobre fuentes aragonesas. Calamocha (Teruel), 5-7 de diciembre de 1991).

25 Así lo hice en Blasco, Los judios del reino de Aragón: Balance de los estudios realizados y perspectivas (cit. en la nota 1), págs. 15-22.

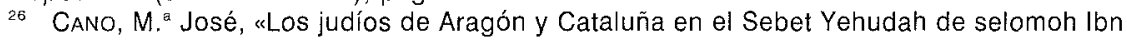
Vergan, en Ir Colloqui d'Història dels jueus a la Corona d'Aragó (Institut d'Estudis llerdencs, Lleida 1991), págs. 167-177.

27 Conde y Delgado de Molina, Rafael, La expulsión de los judíos de la Corona de Aragón. Documentos para su estudio. Zaragoza, Institución Fernando el Católico, 1991.

26. Motis Dolader, Miguel Ángel, Ordinaciones de la alcabala de la aljama judia de Huesca. Edición e indices. Zaragoza, Anubar, $1990 \mathrm{y}$ The Expulsion of the Jews from Calatayud 1492-1500. Documents and Regesta, The Henk Schussheim Memorial Series. Jerusalem 1990. 
hace años viene realizando «The Central Archives for the History of the Jewish People» y la Universidad Hebrea de Jerusalén, que para la parte hispana cuenta con el no menos valioso asesoramiento de Yom Tov Assis.

Por lo que se refiere a las fuentes documentales hebreas, la utilización de los Responsa - uno de los caballos de batalla de Romano, del que en su día me hice eco ${ }^{29}$ - ha permitido a algunos especialistas (concretamente a Assis, Gutwirth y Orfali ${ }^{30}$ ) ahondar en temas ya conocidos por la información recabada en la documentación cristiana, pero desde nuevas perspectivas. Fruto de esta utilización conjunta de fuentes judías y cristianas son las recientes aportaciones de Yom Tov Assis acerca del descontento social y de la agitación religiosa registrada en la sociedad judía aragonesa de la Baja Edad Media ${ }^{31}$.

\subsection{Estudios generales: conversos, Inquisición, expulsión}

En cuanto a los estudios generales sobre el reino Aragón, la historia de los judíos en la España cristiana de Baer ${ }^{32}$ todavía sigue siendo lo mejor que se ha escrito sobre la historia externa de los judíos hispánicos: hay varios capítulos dedicados a la Corona de Aragón y no resulta difícil entresacar lo que se refiere al Reino. El contenido de esta gran obra se completa con los Estudios sobre la historia de los judíos del reino de Arágón durante los siglos XIII y XIV, tesis doctoral del mencionado autor, traducida al español con un título desde mi punto de vista poco acertado, pues no sólo no es representativo sino que induce a confusión respecto del estudio anteriormente citado ${ }^{33}$. Las publicaciones recientes sobre el

29 Blasco, Los judíos del reino de Aragón: Balance de los estudios realizados y perspectivas (cit. en la nota 1), pág. 17.

${ }_{30}$ Orfali, Datos sobre las aljamas del reino de Aragón en los Responsa Rabínica (cit. en la nota 18).

31 Sobre este tema versó la conferencia que Yom Tov Assis pronunció en Ejea de los Caballeros el 12.5.1991, dentro de la "Primera Semana Sefadí de Zaragoza». Véase también ASSIS, Yom Tov; «Ricos y pobres en la sociedad judía de la Sefarad Mediterránea» (en hebreo), Peanim (Ben-Zvi Institute for the Study of Jewish Communities in the East).

32 BAER, Yitzak, Historia de los judios en la España cristiana. Traducción de José Luis Lacave. Madrid, Altalena, 1981; 1 tomo en 2 vols., redactado a partir de los documentos que previamente publicara el autor: BAER, Fritz, Die Juden im christichen Spanien. Urkunden und Regesten. Vol. I: Aragonien und Navarra (en adelante, BAER: JCS). Berlín 1929, reimpresión Greg. England 1970.

${ }_{33}$ BAER, Fritz (Yitzhak), Historia de los judios en la Corona de Aragón (siglos XIII y XIV). Diputación General de Aragón, Zaragoza 1985. [Traducción de la tesis doctoral de Baer que se titulaba Studien zur Geschichte der Juden im Königreich Aragonien während des 13. und 14. Jahrhunderts, Verlag E. Ebering, Berlin 1913]. 
tema, de magnífica presentación, son meramente divulgativas: se limitan a reproducir las ideas y los conceptos expuestos en la biliografía y carecen de aparato crítico $^{34}$.

Aparte de esta visión global de la vida judía en Aragón, podemos distinguir varias etapas y campos claramente diferenciados.

En primer lugar, la Alta Edad media (siglos V-x॥l), que para la Corona de Aragón ha sido estudiada recientemente por Romano ${ }^{35}$. Haciéndonos eco de cuanto él dijo en León, es preciso insistir en que no se ha investigado sobre temática judía en ninguno de los tres períodos diferenciados en esos largos años (visigodo, musulmán y cristiano) porque no se han encontrado nuevos documentos, textos o lápidas que lo permitan.

Por lo que se refiere al siglo XIII -es la época dorada de los judíos de Aragón-, si exceptuamos los estudios de los que dí cuenta hace dos años ${ }^{36}$, poco nuevo tenemos que añadir al respecto, aunque se dispone de abundante documentación oficial para la segunda mitad del siglo y la longitud breve de algunos reinados se presta a realizar estudios monográficos. La razón de esta penuria sin duda radica en la inexistencia de fuentes locales y en las dificultades (económicas y académicas) que los investigadores aragoneses -en teoría deberían ser los más interesados en estos temas - tienen que superar para consultar, de forma sistemática, los fondos del Archivo de la Corona de Aragón, en Barcelona.

Cuanto se ha dicho para el siglo XIII puede ser válido para el XIV, salvo en el caso de Zaragoza, pues desde 1316 se conservan protocolos notariales - son bastantes, aunque menos de lo que sería deseable- que permiten abordar el estudio de la historia interna de la comunidad. La documentación local del siglo xIv relativa a otras aljamas del Reino es mucho más reducida, según se ha puesto de manifiesto en los estudios realizados sobre las comunidades de Épila y Tarazona ${ }^{37}$. No queda do-

\footnotetext{
${ }^{34}$ Motis Dolader, Miguel Ángel, Los judíos de Aragón en la Edad Media (siglos XIII-XIV). Zaragoza, 1990; Caja de Ahorros de la Inmaculada, 1990, y Guía del Aragón judío. Zaragoza, Diputación General de Aragón, 1991.

35 Romano, David, "Judíos hispánicos en los siglos IV-IX», en De la Antigüedad al Medioevo (siglos $N$ al vili), III Congreso de Estudios Medievales. León 23-27.9.1991 (en curso de publicación).

${ }^{36}$ Blasco, Los judios del reino de Aragón: Balance de los estudios realizados y perspectivas (cit. en la nota 1), págs. 26-28.

${ }_{37}$ Sobre los judíos de Épila, véase el estudio de Encarnación Marín, realizado sobre protocolos notariales de La Almunia de Doña Godina y Zaragoza (MARín PADILLA, Encarnación, «La villa aragonesa de Épila en el siglo XIv: sus judíos", Sefarad, XLVII (1987), págs. 315-344). En cuanto a Tarazona, recuérdense los estudios de Sanz Artibucilla (SANz ARTIBUCILLA, José María, "Guillén y Juan de Leví, pintores de retablos", Sefarad (Madrid-Barcelona), IX (1949), págs. 393419), y los más recientes de Ainaga y Motis (MoTIs, Miguel Ángel y AINAGA, M. ${ }^{a}$ Teresa, "Patri-
} 
cumentación municipal del siglo xIV, pero la historia externa puede realizarse a partir de las fuentes oficiales - se guardan en el Archivo de la Corona de Aragón-, que para ese período son especialmente abundantes y muy ricas.

Las investigaciones sobre el siglo XV son mucho más profusas, sobre todo por lo que se refiere a su segunda mitad, pues hay mucha más documentación local (notarial y municipal), especialmente del último período $^{38}$. En cuanto a la estatal, la sigue habiendo, pero no sé donde se guarda, si realmente se conserva. Según mis indagaciones no está toda en el Archivo de la Corona de Aragón. Aunque quedan datos dispersos en los fondos del Archivo del Reino de Valencia, el grueso de la documentación posiblemente se remitió a Zaragoza en 1437, cuando se creó el Archivo de ese Reino, y desapareció en el transcurso de la guerra de la Independencia.

En cualquier caso, hay documentación de la primera mitad del siglo $\mathrm{xV}$, y más concretamente del reinado de Alfonso el Magnánimo, que apenas se ha estudiado y más de una vez me he preguntado por qué. Seguramente ha contribuido a ello que se trate de un período cronológicamente largo, como ocurre en el caso de Pedro el Ceremonioso ${ }^{39} \mathrm{Y}$, sobre todo, que en esos años la vida transcurra en las aljamas de forma anodina: no hay hechos destacados, especialmente en el reino de Aragón, y las aljamas tratan de sobrevivir emulando lo anterior. Las nuevas disposiciones suelen ser meras confirmaciones (o rectificaciones) de lo establecido con anterioridad, en claro contraste con lo que había sucedido en el siglo XIII —es el siglo de oro de los judíos aragoneses-o en el XIV, época de grandes cambios y conquistas en el camino hacia el afianzamiento autonómico de las comunidades judías y cristianas de Aragón. Conviene recordar que en el aspecto político es el siglo de las constituciones $u$ ordenaciones, del reforzamiento del consejo en detrimento del

monio urbanístico aljamial de la judería de Tarazona (Zaragoza): las sinagogas, la necrópolis y las carnicerías", Revista de Historia Jerónimo Zurita (Zaragoza), 56 (1987), págs. 83-129; y AlNAGA, M. ${ }^{a}$ Teresa y Motis, Miguel Ángel, "La judería de Tarazona: delimitación y morfología (1366-1500), Destierros Aragoneses. I: Judíos y moriscos. Zaragoza 6-8 de noviembre de 1986. Zaragoza, Institución Fernando el Católico, 1988, págs. 135-154; MotIs DoLader, Miguel Ángel, "Convulsiones finiseculares y conflictividad social: la aljama judía de Tarazona y los pogroms de 1391", I Encuentro Nacional sobre la Comarca del Moncayo (Tarazona 1989).

${ }_{38}$ Motis Dolader, Miguel Ángel, Líneas programáticas de la legislación sobre judios y conversos en el reino de Aragón en el siglo xv, Congreso Internacional «La Península Ibérica en la Era de los Descubrimientos. 1391-1492", III Jornadas Hispano-Portuguess de Historia Medieval, Sevilla 25-30.11.1991

39 El único estudio que conozco sobre dicho reinado es el de Romano (Romano, David, Els jueus de la Corona d'Aragó en temps de Pere el Ceremoniós (cit. en nota 13), pás. 113-131. 
poder ejecutivo y de la implantación de la figura del clavario o tesorero. En lo que atañe a la cuestión fiscal, se regulan las tallas y se establecen los impuestos indirectos (o sisas). En el campo del derecho, culmina la autonomía judicial de las aljamas que van a tener jueces propios para resolver sus asuntos internos (tribunal ordinario, o Bet din, y tribunal especial, para el juicio de los malsines); mientras, en el ámbito social se adquiere conciencia de grupo (las manos), al que se pertenece en función de la situación económica y social de cada individuo ${ }^{40}$. Las clases menos favorecidas empiezan a reivindicar derechos, lo que les lleva a asociarse, al principio con fines benéfico-asistencial es $y$, cada vez más, con la intención de protegerse de la competencia en el mundo laboral.

A comienzos del siglo $\mathrm{xV}$ algunas aljamas desaparecen ${ }^{41}$ y otras (la mayoría) entran en una fase de acusado declive aunque consiguen estabilizarse y sobrevivir. Mientras, se desarrolla y toma fuerza el problema converso ${ }^{42}$ y se ponen los cimientos de la Inquisición ${ }^{43}$, que por ser de la herética pravedad debía extender su jurisdicción sobre los conversos, no sobre los judíos. Estos dos asuntos (conversos e Inquisición), junto con la expulsión, han monopolizado la atención de los historiadores por lo que suponen de innovación en la historia de los judíos hispánicos y por las muchas sugerencias que su estudio ha planteado y todavía suscita. No es de extrañar que el estudio de las comunidades, cada vez menos influyentes, haya quediado relegado a un segundo plano. Hay excepciones: las que recogí en 1989 sobre los judíos de Borja y Magallón ${ }^{44}$ y,

40 Parece ser que los artesanos, incluso los más apreciados, estaban adscritos a la mano mediana.

41 Es el caso de las aljamas de Alcañiz (LALIENA, Orígenes y extinción de una aljama judaica: Alañiz, 1280-1414 (cit. en la nota 22) y Daroca (MOTIS DOLADER, Miguel Ángel, «Disappearence of the Jewish Community of Daroca at the Beginning of the XV th Century", Proceedings of the Tenth World Congress of Jewish Studies, Division B, vol. II: The History of the Jewish People (Jerusalem 1990), págs. 143-150.

42 De la aparición del problema conversc me he ocupado en anteriores trabajos (BLASCO, Los judíos del reino de Aragón: Balance de los estudios realizados y perspectivas (cit. en la nota 1), y Blasco Martínez, Asunción, «El impacto de los ataques de 1391 y del adoctrinamiento de Tortosa en la sociedad judía aragonesa", en La Península lbérica en la Era de los descubrimientos, III Jornadas hispanoportuguesas de Historia Medieval, Sevilla 25.11-1.12.1991 (en curso de publicación), § 4.3.2. Sobre los judeoconversos oscenses versa un estudio de Federico BaLAguer SÁNCHEZ, que será publicado en breve.

43 Véase Sesma Muñoz, José Ángel, Violencia institucionalizada: el establecimiento de la Inquisición por los Reyes Católicos en la Corona de Aragón y El establecimiento de la Inquisición en Aragón (1484-1846). Documentos para su estudio (cit. en la nota 12).

44 Motis Dolader, Miguel Ángel, «Los judíos de Borja en el siglo xv, Cuadernos de Estudios Borjanos (Borja) XIX-XX (1987), págs. 33-34. Como djje hace dos años, el título no expresa con claridad lo que realmente se aporta, pues toda la documentación utilizada es de la segunda mitad del siglo XV, escepto un registro notarial de 1418 (BLAsco), Los judíos del reino de Aragón: Balance de los estudios realizados y perspectivas (cit. en la nota 1), pág. 91, nota 456). Del 
sobre todo, el amplio y documentado trabajo que sobre la aljama de La Almunia de Doña Godina ha realizado Encarnación Marín y al que me referiré más adelante.

Como hemos visto e iremos viendo a lo largo de la presente exposición, en la segunda mitad del siglo xv aumenta considerablemente la cantidad de documentación local (municipal, notarial) y, en consecuencia, el número de publicaciones. Este incremento es especialmente acusado en el caso de la expulsión, tema que aunque ha sido ampliamente estudiado por Motis ${ }^{45} \mathrm{y}$, en menor medida, por Orfali ${ }^{46}$ y Beatriz Leroy ${ }^{47}$, sigue planteando numerosos interrogantes. En este sentido cabe destacar la valiosa aportación de Rafael Conde, que en la introducción a la colección documental sobre la expulsión de los judíos de la Corona de Aragón defiende la existencia de varios edictos de expulsión: uno para la Corona de Castilla y otro para la de Aragón, posiblemente redactados a partir de un decreto, de dudosa legalidad, firmado por Torquemada en Sta. Fe a 20 de marzo ${ }^{48}$. Cabe esperar que los partidarios y detractores de esta teoría lleguen a un acuerdo a lo largo del próximo año, pues son muchas las reuniones científicas que se están preparando para conmemorar el quinto aniversario del éxodo de los judíos hispánicos. La incidencia del edicto de 1492 sobre la judería oscense ha sido analizada por Balaguer en un artículo dedicado a la familia Argelet ${ }^{49}$.

El tema de la expulsión -lo he dicho y lo repito- está en el candelero. En este año en que se conmemoran los seiscientos años de los ataques a muchas juderías de la Península, la proximidad del «Quinto Centenario» está restando protagonismo a unos hechos que fueron, por lo menos, tan luctuosos como la expulsión, pues hubo muertos y violencia incontrolada.

mismo autor, véase «Judíos y judeoconversos en la Raya Occidental de Aragón (siglos XII-XV), I Jornadas Borja y la Raya Occidental. Borja 1989. De los estudios sobre Magallón di cuenta en la obra citada, pág. 23 (nota 44) y 56 (nota 222).

45 Motis Dolader, Miguel Ángel, Los judíos aragones en la época del descubrimiento de América. Zaragoza, Diputación General de Aragón, 1989 (Colección Aragón y América) [sin aparato crítico], y La expulsión de los judíos del reino de Aragón. Zaragoza, Diputación General de Aragón, 1990, 2. vol.

46 En un artículo en colaboración, Motis y Orfali se hacen eco de la idea lanzada por Conde (Motis, Miguel Ángel; Orfall, Moisés, "Ha nusah mi gezerah mi-haglayah min Sefarad An Analysis of the Version of the General Edict of Expulsion from Spain and its Investigation], Peanim (Ben-Zvi Institute for the Study of Jewish Communities in the East, Jerusalem 1991).

${ }_{47}$ Leroy, Béatrice, L'expulsion des juifs d'Espagne. París, Berg International Ed., 1990.

4a CONDE, La expulsión de los judíos de la Corona de Aragón (cit. en la nota 27), págs. 914.

49 Balaguer SÁnchez, Federico, «Los Argelet durante la expulsión de los judíos oscenses (1492)", Argensola, n. ${ }^{\circ} 104$ (1990), págs. 9-33; y, sobre todo, La expulsión de los judíos oscenses en 1492 (en curso de publicación). 
Pero mientras que los acontecimientos de 1391 no tuvieron carácter político, en 1492 se tomó una postura «oficial» contra los judíos y se adoptaron unas medidas drásticas para desterrar a los que se empeñaron en seguir fieles a su religión. No pretendo restar importancia al edicto de 1492: sin duda fue un hecho dramático, pues muchos individuos se vieron obligados a abandonar algunas de sus pertenencias más queridas, sus casas $y$, en fin, la tierra que les había visto nacer. Sencillamente trato de reivindicar la importancia de los alborotos de 1391 y del adoctrinamiento de Tortosa para la historia de los judíos hispánicos, porque la tuvo, aunque la sociedad actual no se haya percatado de ello. Aunque los estudios pormenorizados sobre estos hechos son escasos, está demostrado que el número de conversiones contabilizado en los últimos años del siglo XIV $y$ en los primeros del $x v$ fue muy elevado.

La expulsión fue el capitulo final de una triste historia que empezó a escribirse con letras de sangre en 1391. De entonces arrancan las conversiones en masa, la desaparición de algunas aljamas y el declive del judaísmo en Castilla y en diversos estados de la Corona de Aragón: Cataluña, Valencia, Mallorca. El adoctrinamiento de Tortosa (1413-1414), de apariencia mucho más pacífica, asestó el golpe de gracia a la judería del reino de Aragón que en 1391 se había librado de la agresión. Como hemos dicho recientemente, los alborotos de 1391 y la reunión de Tortosa fueron dos campañas para acabar con el judaísmo hispano: la primera trató de lograr la conversión mediante la violencia y el terror y consiguió excelentes resultados en amplios sectores de la judería hispana. Para concluir la tarea y extender los resultados al reino de Aragón se organizó una segunda ofensiva; pero en esta ocasión la Iglesia -era la principal interesada en la conversión de los judíos y la responsable directa de estas actuaciones antijudías- propuso un cambio de táctica para mejorar su imagen, que había quedado dañada tras los acontecimientos del 91: habia que convencer a los dirigentes e intelectuales judíos mediante la palabra con la esperanza de que su ejemplo hiciera mella en todos los sectores de la sociedad judía ${ }^{50}$.

\subsection{Comunidades locales y urbanismo}

En los últimos años se observa un intento de reconstruir la historia de las aljamas de los judíos de Aragón. La primera que se estudió en pro-

50 Blasco, El impacto de los ataques de 1391 y del adoctrinamiento de Tortosa en la sociedad judía aragonesa (cit. en la nota 42). 
fundidad - mediante la utilización conjunta de documentación local y oficial - y durante un período de tiempo que, por su amplitud, permitía sacar conclusiones fue la de Zaragoza ${ }^{51}$. Es un tema en el que sigo trabajando, sin prisas pero sin pausas, pues aunque se han aclarado muchas cosas acerca de la actividad laboral de sus gentes ${ }^{52}$, costumbres alimenticias y ritos ${ }^{53}$, hay puntos y aspectos que todavía no están dilucidados: por ejemplo, no se conocen los estatutos por las que se rigió la comunidad hasta 1382, aunque hay indicios de su existencia; interesa captar el ambiente en el que coexistían judíos y cristianos en vísperas de la aparición de la Peste Negra, sin duda más convulsivo de lo que se creía hasta ahora; y, sobre todo, es preciso conocer la realidad social del Reino cuando, como consecuencia de lo acaecido en Tortosa, empieza a despuntar el problema converso ${ }^{54}$.

Recientemente Encarnación Marín ha abordado el estudio de dos aljamas aragonesas: la de Épila, a partir de unos pocos registros notariales del siglo XIV conservados en el Archivo Notarial de Zaragoza ${ }^{55}$, y la señorial de La Almunia de Doña Godina, tomando como base los datos registrados para esa centuria en los protocolos notariales de la segunda mitad del siglo xv que se guardan en esa villa. Este último estudio abarca los principales aspectos de la vida de la comunidad, desde el urbanístico (sinagoga, hospital, carnicería, cementerio, etc.), pasando por la organización interna (órganos de gobierno, cargos, organización fiscal) y la con-

51 Como ya hice en mi tesis doctoral: Blasco MarTínez, Asunción, Los judíos de Zaragoza en el siglo XIN (Zaragoza 1987), 10 vol. Hasta la fecha únicamente se ha publicado el primer volumen (Blasco Martínez, Asunción, La judería de Zaragoza en el siglo xIV. Zaragoza, Institución Fernando el Católico, 1988), pero se incluye un detallado índice de la misma en la ponencia Blasco Martínez , Asunción: «Los judios de Zaragoza. Un modelo para investigación» en Jornades d'Història dels jueus de Catalunya. Girona abril 1987 (Girona, Ajuntament, Girona, 1990), págs. 177-215 y 217-22i, y un resumen general, sin notas, en BLAsco MARTínEZ, Asunción, "Los judios de la aljama de Zaragoza», en De Sefarad: Los judios en la Corona de Aragón en los siglos XN y XV. Valencia, Generalitat Valenciana y Doron Foundation for Education and Welfare, 1989, págs. 77-94.

52 Blasco MARTínez, Asunción, "Actividad laboral de una comunidad urbana del siglo xIv: la aljama de judios de Zaragoza», en Les sociétés urbaines dans la France méridionale et la Péninsule Ibérique au Moyen Age. Pau 21-24.9.1988 (Paris 1990), págs. 430-461.

53 Blasco Martínez, Asunción, «Significado del término matar en el aragonés medieval: un carnicero cristiano contratado para matar el taller carne en la aljama de judíos de Zaragoza en 1401", Archivo de Filología Aragonesa, XLII-XLII (1989), págs. 249-274; y "La producción y comercialización del vino entre los judíos de Zaragoza (siglo xIv)", Anuario de Estudios Medievales, 19 (1989), págs. 409-449.

54 BLASCO, El impacto de los ataques de 1391 y del adoctrinamiento de Tortosa en la sociedad judía aragonesa (cit. en la nota 42).

${ }_{55}$ Marín, Encarnación, La villa aragonesa de Épila en el siglo XIV: sus judíos (cit. en la nota $37)$. 
formación social, lo que permite considerar el potencial económico de sus miembros, la dedicación laboral y profesional de sus gentes e incluso la genealogía de las principales familias, amén de la realidad social de la aljama propiamente dicha y de sus componentes en relación con sus vecinos cristianos ${ }^{56}$. En breve, la mencionada investigadora publicará un estudio sobre la aljama de Épila en el siglo $\mathrm{XV}^{57}$ y otro dedicado a los judíos de lllueca y Arándiga.

También se han estudiado aspectos de otras aljamas aragonesas (Alagón, Borja, Daroca, Magallón, Huesca ${ }^{58}$ ), a partir de las fuentes locales que, en general, son tardías: proceden del siglo $x \vee$ y casi siempre de la segunda mitad.

Uno de los grandes inconvenientes con que tropieza el historiador al tratar de reconstruir el ámbito material en el que los judíos vivían es la inexistencia de restos materiales con los que fundamentar, y muchas veces aclarar, lo que dicen o parecen querer decir los documentos, que en ocasiones proporcionan datos de extraordinario interés ${ }^{59}$. Si hacemos un recuento de los materiales arqueológicos de que se dispone para hacer el estudio urbanístico de las juderías de Aragón, los resultados no pueden ser más desalentadores: por lo que se refiere a edificios (concretamente sinagogas y baños), hay hipótesis y tradiciones, pero pocas seguridades ${ }^{60}$. Esperamos con impaciencia los resultados del amplio y documentado estudio de J. L. Lacave sobre las juderías de los estados hispánicos ${ }^{61}$.

En cuanto a los cementerios, aunque la bibliografía se ha incrementado ${ }^{62}$, no se sabe ahora mucho más que hace tres años. Las inscrip-

56 Marín Padilla, Encarnación, «Los judíos de la Almunia de Doña Godina, villa aragonesa de señorío, en la segunda mitad del sigio XV», Sefarad, XLiX (1989), págs. 135-152 y 263-306; L (1990), págs. 85-127 y 335-371, y Ll (1991), págs. 51-84 y 299-337.

57 Dicho estudio se halla en curso de publicación.

5o Por lo que se refiere a Alagón, véase PÉrez P., Judios en Alagón (cit. en la nota 11) y Alagón en la Edad Media (cit. en la nota 11), págs. 42-48. Para Daroca, Borja y Magallón, véanse las notas 41 y 43 . Acerca de Huesca, véase la breve nota de BALAGUER SÁnCHEz, Federico, «La casa de la Mezquita en la judería oscenses", Argensola, 104 (1990), págs, 251-252.

sa Según se ha puesto de relieve al estudiar la judería de Zaragoza (BLAsco, La judería de Zaragoza en el siglo XIV (cit. en la nota 51) y en otras juderías menores como Borja (MOTIS DOLADER, Miguel Ảngel, "La judería de Borja», en Evolución urbanística de la ciudad de Borja. (Zaragoza, 1988). La Almunia de Doña Godina (MARín, Encarnación, Los judíos de la Almunia de Doña Godina (cit. en la nota 56) y Épila (MARín, Encarnación, La villa aragonesa de Épila (cit. en la nota 37, y MotIS DOLADER, Miguel Ángel, Articulación y funcionalidad del barrio judío de Épila en el siglo xv; convivencia o segregación, Congreso Internacional «Judíos y conversos en la Historia", Ribadavia, 14-17 de octubre de 1991).

6o Una de las sinagogas más fiables sería la de Híjar.

61 Lacave ya ha dado a conocer algunos en la revista Sefarad.

62 El reciente artículo de Motis sobre el cementerio de Zaragoza no aporta novedades respecto a lo que ya se había dicho en la bibliografía a la que, por cierto, no hace referencia alguna 
ciones hebreas son escasas - yo mejor diría casi inexistentes- si exceptuamos la lápida de la calle Trévedes, en El Frago. Otro tanto podemos decir acerca de los objetivos, que además de escasos ${ }^{63}$ ofrecen serias dudas acerca de su procedencia judía: me refiero, por ejemplo, a la lamparita y a la campana, supuestamente de uso judío, que se guardan en el Museo Provincial de la Zaragoza: nada, ni siquiera los símbolos que las decoran, permiten asegurar que se trate de objetos empleados por judíos ${ }^{64}$.

Se impone la necesidad de excavar en cementerios y lugares donde antaño se asentaron comunidades judías. Posiblemente aparezcan, como sucedió en Teruel ${ }^{65}$, anillos y sellos, que apenas se han estudiado. Sin embargo, sabemos que los judíos aragoneses de un determinado rango social utilizaron sellos para autenticar sus documentos: es el caso del tortosino Momet Alfavell, que en torno al año 1380 se trasladó a Zaragoza, donde fijó su residencia tras contraer matrimonio con Dueña Abnarrabí, hija del adinerado Salomón. Momet, que siguió manteniendo estrecha relación con comerciantes de Cataluña e intervino en diversas misiones diplomáticas al servicio del Rey y del Infante, tenía sello propio que se conoce gracias a la descripción hallada en documentos coetáneos ${ }^{66}$. Otros judíos de alcurnia (como los Caballerí, los Benvenist, etc.), que llegaron a ser administradores de los reyes y de otras dignidades cristianas (el arzobispo de Zaragoza, el Castellán de Amposta, etc.), seguramente tuvieron sello propio, de los que nada sabemos.

(Motis Dolader, Miguel Ángel, «El cementerio judío de Zaragoza», en Las necrópolis de Zaragoza. Zaragoza, Ayuntamiento de Zaragoza, 1991, págs. 67-83). Por su parte, Federico Balaguer ha realizado un estudio sobre los Cementerios judios de Huesca cuya publicación es inminente.

63 Acerca de las lámparas rituales halladas en Teruel, véase Atrián JORDán, Purificación, "Lámparas de Hanukkah en cerámica popular turolense», Teruel, julio-diciembre (1981), págs. 175-180 (recogido en BLASCO; Los judíos del reino de Aragón: Balance de los estudios realizados y perspectivas (cit. en la nota 1), pág. 15, nota 8 ).

64 Sobre los objetos encontrados en Monzón, véase VILADÉS CASTILLO, M. ${ }^{a}$ José, “Materiales procedentes de la sinagoga de Morizón (Huesca) en el Museo Provincial de Zaragoza», Boletín de la Asociación Española de Orientalistas (Madrid), XX (1984), págs. 307-315 (recogido en BLASCO, Los judíos del reino de Aragóri: Balance de los estudios realizados y perspectivas (cit. en la nota 1), pág. 16, nota 9).

${ }_{65}$ En las excavaciones realizadas en 1962 en tres tumbas de la necrópolis judía de Teruel aparecieron joyas y otros objetos que posiblemente formaban parte del ajuar funerario de algún miembro de la aljama. Véase la Memoria del Museo de Teruel de 1962. Algunas de las piezas están bellamente reproducidas en «La vida judía en Sefarad", Sinagoga del Tránsito, Toledo 1991 (Ministerio de Cultura, Dirección General de Bellas Artes y Archivos, Centro Nacional de Exposiciones, Madrid 1991), págs. 278-280.

${ }_{66}$ Blasco Martínez, Asunción, "El sello del judío Momet Alfavell y la personalidad de su titular (siglo XIV)", Actas del Primer Coloquio de Silografía. Madrid, 2 al 4 de abril de 1987. Madrid, Dirección de los Archivos Estatales, 1990, págs. 287-298. 


\subsection{Sociedad e instituciones sociobenéficas}

Uno de los tópicos antijudíos que mayor fuerza sigue teniendo hoy, a fines del siglo $\mathrm{xx}$, es la creencia de que casi todos los judíos hispánicos se dedicaban al préstamo y al comercio. Se ha referido a ello Romano, y yo misma he denunciado este hecho en diversas ocasiones: la última hace unos días en Sevilla, cuando aludía a la existencia e incluso abundancia de judíos pobres e indigentes en muchas de las aljamas aragonesas durante los siglos XIV y XV: "sólo así --decía- se explica el elevado número de hospitales e instituciones benéfico-asistenciales registrado" en Zaragoza, Huesca, Épila o Calatayud ${ }^{67}$.

El estudio de las instituciones sociobenéficas se ha hecho para Zaragoza, donde al filo de los siglos XIV-XV se documentan un mínimo de once agrupaciones benéfico-asistenciales y tres de carácter laboral ${ }^{68}, y$ puede hacerse extensivo a otras aljamas, como las ya citadas o la de La Alumnia de Doña Godina, pues en las fuentes oficiales cristianas se encuentran las actas de fundación de las cofradías judías, mientras que las noticias sobre su funcionamiento se hallan registradas en los protocolos notariales coetáneos: allí se conservan los nombres de sus dirigentes o adelantados, la nómina de sus asociados e incluso la relación de los bienes patrimoniales de la hermandad y la noticia de litigios que ocasionalmente surgieron en relación con estas propiedades, la ubicación del local social y otras muchas noticias de interés. En otro orden de cosas, la consulta de las fuentes hebreas (los Responsa) permitirán - para el caso de Zaragoza ya es una realidad gracias a la labor realizada por Yom Tov Assis ${ }^{69}$-ampliar lo que en su día se dijo sobre las cofradías y, sobre todo, proporcionar nuevos enfoques y obtener otros datos acerca de la realidad social de aljamas aragonesas bajomedievales.

\footnotetext{
67 Blasco, El impacto de los ataques de 1391 y del adoctrinamiento de Tortosa en la sociedad judía aragonesa (cit. en la nota 42), $\$ 2.4$ (en curso de publicación).

68 Blasco Martínez, Asunción, «Instituciones sociorreligiosas de los judíos de Zaragoza (Siglos XIV-XV). Sinagogas, cofradías, hospitales", Sefarad, XLIX (1989), págs. 227-236 y L (1990), págs. 3-46 y 265-288. Con los datos que he ido acumulando hasta la fecha, no abandono la idea de hacer un estudio más amplio, de todo el reino de Aragón.

69 Assis, Ricos y pobres en la sociedad judía de la Sefarad mediterránea (cit. en la nota 31).
} 


\subsection{Cuestiones judiciales y derecho}

Se ha examinado el largo camino recorrido por algunas aljamas en la consecución de su autonomía judicial ${ }^{70}$, como paso previo para el conocimiento del sistema judicial propiamente dicho ${ }^{71}$, tema en el que apenas se ha profundizado debido a la escasez de procesos judiciales estrictamente judíos conservados tanto en la capital del Reino ${ }^{72}$ como en otras ciudades ${ }^{73}$. Hasta la fecha, que yo sepa, sólo se han publicado unos pocos procesos de estas características, fundamentales para conocer el funcionamiento de los tribunales judíos y su jurisdicción.

Por su relación con los jueces judíos, parece oportuno decir unas breves palabras acerca de los notarios, un tema sobre el que se ha investigado poco ${ }^{74} \mathrm{y}$ al que considero que debería prestarse un poco más de atención, pues los notarios judíos desempeñaron un importantísimo papel en la vida interna de las aljamas aragonesas en los siglos XIV y XV, es decir, poco después de que se produjera el afianzamiento de la institución notarial cristiana.

El estudio del marco jurídico en el reino de Aragón no se ha realizado, quizá porque, como ha apuntado Romano, «no puede hacerse con la misma facilidad que para Castilla» ${ }^{75}$. La principal dificultad estriba en que todavía no se ha abordado la recopilación y publicación de todos los acuerdos de Cortes relativos al Reino ${ }^{76}$.

70 Blasco Martínez, Asunción, "La autonomía judicial de los judíos de Zaragoza: La normativa de 1376", Sefarad (1992) (en prensa).

${ }^{71}$ BLASCO, Los judíos de Zaragoza en el siglo xIV (cit. en la nota 51), capítulo IV (Inédito).

72 LaCAVE RIAÑo, José Luis, «Pleito judío por una herencia en aragonés y caracteres hebreos. Notas acerca del procedimiento judicial en los tribunales judíos aragoneses", Sefarad (Madrid-Barcelona), XXX (1970), págs. 325-337 y XXXI (1971), págs. 49-101; BLAsCo MARTíneZ, Asunción, "Avance de estudio de un caso de adulterio en la aljama de Zaragoza (siglo XIV)", Proceedings of the Tenth World Congress of Jewish Studies, Division B, vol. II: The History of the Jewish People (Jerusalem 1990), págs. 105-112, "El adulterio de doña Lumbre, judía de Zaragoza, causas y consecuencias", Michael (Tel Aviv), Xl (1989), págs. 99-120.

${ }_{73}$ Sobre cierto proceso llevado a cabo en Calatayud, véase MARín PADILLA, Encarnación, «En torno a una demanda de pago o rabí Aãch Arama ante los dayyanim de Calatayud (Siglo XV', Michael. On the History of the Jews in the Diaspora (Tel-Aviv), XI (1989), págs. 142-148.

74 Blasco Martínez, Asunción, «Notarios-escribanos judíos de Aragón (siglos XIV-XV)», En Congrès International Rashi, organizado por la «Association pour la promotion des Etudes Juives en Europe", Troyes 8-13 juillet 1990. (Paris 1992).

75 Romano, Perspectivas de la Historia judía de la Corona de Aragón (cit. en la nota 2), § 4.1 .

76 Existe una propuesta de Motis que pretende adaptar al reino de Aragón lo que Pilar León (LEón TelLo, Pilar, «Legislación sobre judíos en las Cortes de los antiguos reinos de León y 
En los útimos años se han publicado diversos trabajos relacionados con el derecho de los judíos aragoneses, especialmente con el sucesorio. La documentación utilizada ha sido siempre cristiana, notarial y del siglo $x v$; pero la zona geográfica estudiada (Zaragoza ${ }^{77}$ y Épila) e incluso el período cronológico examinado (en unos casos, los primeros años del siglo $x V y$, en otros, la segunda mitad) ha sido amplio, lo que ha permitido obtener una visión generalizada de cómo realizaban los testamentos los hombres y las mujeres que habitaban en la judería en el siglo xv, de sus preocupaciones ante la muerte y, icómo no!, de sus bienes patrimoniales. La investigación desarrollada, amén de arrojar luz sobre la situación de la mujer en el seno de la sociedad judía y de proporcionar datos novedosos sobre la legislación particular de cada comunidad — ahora sabemos que los judíos zaragozanos estaban autorizados a plasmar por escrito su última voluntad en cualquier momento de su vida, sin tener en cuenta la condición de "estar enfermo" exigida por la Ley hebrea-, explica y justifica el aumento de testamentos de judíos y judías aragoneses registrados ante notario cristiano a lo largo del siglo $\mathrm{xv}$, íntimamente ligado al fenómeno converso que rompió la cohesión de algunas familias judías ${ }^{78}$.

Igualmente interesante es el asunto de la segunda esposa, que los judíos de Aragón podian tener si el rey les daba permiso para ello. El monarca solía dar su autorización de forma automática siempre que el solicitante reuniera unos requisitos mínimos (falta de descendencia, mala

Castilla», Fouth World Congress of Jewish Studies, II (Jerusalem, 1968), págs. 55-63), Romano (Romano, David, “Marco jurídico de las minorías judías en la Corona de Castilla de 1214 a 1350. (Síntesis y propuestas de trabajo)", en Actas del II Congreso Internacional: Encuentro de las tres Culturas. Toledo, Ayuntamiento, 1985, págs. 261-291. Este trabajo está reproducido en Romano, David, De historia judia hispánica. Barcelona, Universitat de Barcelona, 1991, págs. 341-371) y Monsalvo (Monsalvo Antón, José María, «Cortes de Castilla y León y minorías», en Las Cortes de Castilla y León en la Edad media. (Valladolid, 1988), págs. 143-191) han hecho para Castilla (Motis Dolader, Miguel Ángel, Acceso metodológico del estudio de la minoría étnico-confesional judía en la Edad Media de las "actas de cortes", "IV Jornadas de Metodologia de la Investigación Científica sobre Fuentes Aragonesas» (Zaragoza 1989), págs. 373-384.

77 El estudio de los testamentos de judios aragoneses cuenta con las interesantes aportacioens de Serrano (SerRano y Sanz, Manuel, Orígenes de la dominación en América. Madrid 1918, págs. CLXXXVI-LLXXXVII y CCLVII y CCCCLXXVII), y sobre todo de Cabezudo (CABEZUDO AStRaIN, José, «Testamentos de judíos aragoneses», Sefarad, XVI (1956), págs. 136-147), Marín (MARIN PAdILLA, Encarnación, «Ultimas voluntades judías: testamentos de Duenya Falaquera, Reyna Abenardut y Davit Rodrich (siglo xv), Anuario de Estudios Medievales, 15. Barcelona, 1985, 497-512); Motis (Motis DOladeR, Miguel Ángel, «Disposiciones "mortis causa" de los judíos de Épila (Zaragoza) en el último tercio del siglo xV, Aragón en la Edad Media, VIII (1989), 475-498), y Blasco (BLASCO MARTINEZ, Asunción, "Testamentos de mujeres judías aragonesas», Proceedings of the Tenth World Congress of Jewish Studies, Division B, vol. II: The History of the Jewish People. Jerusalem 1990, págs 127-134.

${ }_{78}$ Véase Blasco Martinez, Asunción, «Mujeres judías zaragozanas ante la muerte», Aragón en la Edad Media, IX (1991), págs. 77-120. 
convivencia, malos tratos, etc.) y pagara por la autorización. El permiso real sólo permitirá tener una segunda mujer en vida de la primera, salvo en casos muy especiales (por ejemplo, el de Hasday Crescas), en los que no se fijaba límite ${ }^{79}$. De todo esto se ha ocupado Yom Tov Assis en un reciente artículo ${ }^{80}$.

La cuestión de los esponsales, sobre la que desde hace años trabaja Lacave, sigue planteando interrogantes de enorme interés: convendría encontrar nuevos documentos de repudio (mal llamado divorcio) o guet, especialmente frecuentes a finales del siglo XIV y comienzos del ${ }^{\mathrm{x} v}$, cuando se registra un incremento en el número de los judíos casados que se hacen cristianos. La conversión de la mujer también suele generar documentos, dirigidos a recuperar las arras, o dote, que la esposa hubiera aportado al matrimonio.

\subsection{Vida privada: judíos y conversos}

Otro de los temas estrella en estos últimos años ha sido el de la alimentación, quizás como consecuencia de los congresos y reuniones que sobre este asunto se han organizado ${ }^{81}$.

El primero que rompió el fuego en el tema de la alimentación de los judíos fue Lacave, que en el año 70 publicó un artículo sobre la carnicería de la aljama de Zaragoza en el siglo $x V^{82}$. Posteriormente, se ha proseguido la investigación sobre la cuestión ritual alimenticia de la aljama zaragozana en los siglos XIV y XV, tanto en lo que se refiere a la carne ${ }^{83}$ como en lo que atañe al vino, asunto (éste último) sobre el que apenas se había investigado y del que ya se conocen aspectos de indudable interés. Partiendo de la teoría ${ }^{84}$ (ahora confirmada) de que los judíos his-

79 BAER, JCS, $1, n .^{\circ} 452$.

80 Assis, Yomo Tov, "Hérem de-rabenu Gersom we-nissué bé-Sefarad [The Órdinance of Rabbenu Gershom' and polygamous marriages in Spain]", Zion. (Jerusalem), XLVI (5741/19801981), págs. 251-277.

31 En el «l' Col.loqui d'Història de l'alimentació a la Corona d'Aragó», celebrado en Lérida los días 7-9 de noviembre de 1990, Miguel Ángel MoTIS DOLADER presentó una ponencia sobre Dietética y alimentación de los judíos y judeoconversos en la Corona de Aragón, que hasta la fecha no se ha publicado.

82 "La canicería de la aljama zaragozana a fines del siglo XV, Sefarad, XXXV Madrid-Barcelona (1975), págs. 3-35.

83 Blasco Martinez, Asunción, «Significado del término matar en el aragonés medieval: un carnicero cristiano contratado para "matar et tallar" carne en la aljama de judíos de Zaragoza en 1401», Archivo de Filología Aragonesa, XLII-XLlli (Zaragoza), págs 259-275.

84 CASTRO, Américo, "Vino judiego», Revista de Filología Española, Vll (1920), pág. 384; y BLondHEIM, D.S., "Vino judiego", Revista de Filología Española, IX (1922), págs. 180-181. 
pánicos únicamente consumían vino «jodienco» o «judiego», es decir, kasher, se ha podido comprobar que la preocupación de algunos judíos aragoneses por disponer de tierras para el cultivo de la vid, y en su defecto de uvas que les permitieran elaborar su propio vino, era real. Sin embargo, sabemos que la participación de estos mismos judíos en las tareas agrícolas no fue directa, pues aunque algunos - fueron sólo unos pocostuvieron viñas propias o en arriendo, no se ocuparon personalmente de su explotación sino que, para ello, recurrieron a agricultores cristianos. Como la procedencia de la uva no afectaba a la elaboración del vino, muchos judíos (la mayoría) prefirieron comprar el fruto a los proveedores cristianos, con los que ocasionalmente se asociaron en vísperas de la vendimia. Las bodegas de la judería se utilizaron para guardar vino de cristianos en más de una ocasión; en cambio, no consta que los cristianos conservaran en sus casas vino para el consumo de los judíos ${ }^{85}$.

La dedicación laboral de las gentes de la judería aragonesa también ha atraído la atención de los investigadores ${ }^{86}$. Acerca de ello, es interesante observar que en todas las aljamas del reino se ejercían los mismos oficios y profesiones (sastrería, zapatería, comercio, medicina, peletería, platería, etc.) y en una proporción muy similar, salvo en el caso de la agricultura que, según algunos autores era ocupación de los judíos que habitaban en las zonas rurales ${ }^{87}$, pero no de los que residían en zonas urbanas.

El estudio de los judíos francos de Zaragoza (Alazares y Caballería) y Calatayud es un tema anunciado y sobre el que se van haciendo cosas ${ }^{88}$, aunque lentamente: el ritmo es el impuesto por el volumen de

85 Blasco Martinez, Asunción, «La producción y comercialización del vino entre los judíos de Zaragoza (Siglo XIv), Anuario de Estudios Medievales, 19 (1989), págs. 405-449.

${ }^{86}$ Véanse los artículos de Encarnación Marín sobre Épila (cit. en la nota 37) y la Almunia de doña godina (cit. en la nota 56), de Asunzión Blasco sobre Zaragoza (BAsco, Actividad laboral de una comunidad urbana del siglo XIV (cit. en la nota 52) y de Motis acerca de Daroca (Moris Dolader, Miguel Ángel, «Estructura socio-profesional de los judíos de Daroca en la Baja Edad Media", en Ir Colloqui d'Història dels jueus a la Corona d'Aragó. Lleida, Institut d'Estudis llerdencs, 1991, págs. 261-281. El título de este último artículo puede inducir a error, pues el autor únicament maneja documentación del siglo xv, y muy especialmente de su segunda mitad, Acerca de los conversos relacionados con la imprenta, véase MARIN PADILLA, Encarnación, "Pablo Hurus, impresor de Biblias en lengua castellana en el año 1478», Sefarad, 18 (1988), págs. $591-603$.

${ }^{87}$ Acerca de la vida rural de los judíos, puede verse Motis DoLAdER, Miguel Ángel, «Régimen de explotación de las propiedades agrarias de los judíos en el noroeste del reino de Aragón en el siglo XV», Hispania, XLVIII/169 (1988), págs. 405-492.

88 BLASCO, «Mujeres judías zaragozanas ante la muerte (cit. enla nota 78) y BLASCO MARTI. NEZ, Asunción, «Las expulsiones señoriales: los Caballería y los Alazar de Zaragoza, vasallos de la Orden del Hospital», en The Expulsión of the Jews from Spain (1474-1516). Jerusalem, 6 10.1.1992 
documentación que se precisa, distribuida tanto en los archivos locales como en los oficiales. Por tratarse de grupos de poder (sobre todo en el caso de los Caballería), las noticias pueden aparecer en los fondos más insospechados, de dentro y fuera del Reino.

De la relación entre judíos y conversos se ocupó, hace unos años, Encarnación Marín ${ }^{89}$, que no ha dejado de trabajar sobre el tema ${ }^{90}$.

En la actualidad, las relaciones de los judíos con sus vecinos musulmanes preocupan a varios investigadores, la mayoría extranjeros. Elena Lourie, la más veterana en esta lides, atiende a las relaciones entre los componentes de estas dos comunidades en la Corona de Aragón, en general, a partir de documentos de los siglos XIII y XIV del Archivo de la Corona de Aragón ${ }^{91}$. En esta misma dirección, aunque con documentación del reinado de Jaime $I I$, se orienta la tesis doctoral que actualmente realiza Nirenberg, de la Universidad de Princeton. Recientemente, Gutwirth, especialista en el estudio de las mentalidades en el ámbito hispanojudío del siglo $\mathrm{XV}$, nos ha deleitado con un breve pero esclarecedor análisis acerca de la actitud que los judíos hispánicos del siglo XV adoptaron respecto de la otra minoría confesional hispana, la musulmana, de la que recibieron una influencia innegable en lo cultural (uso de la lengua árabe, poesía, estilo arquitectónico, etc.) y con la que conectaron y colaboraron en diversos momentos de su larga coexistencia en suelo hispano ${ }^{92}$. Como he indicado anteriormente. M. ${ }^{a}$ Luisa Ledesma ${ }^{93}$ (que desde hace años investiga acerca de los mudéjares aragoneses) está tratando de averiguar la repercusión que la ruptura de la coexistencia entre cristianos y judíos tuvo en la comunidad mudéjar de Aragón.

89 Me remito a cuanto dije en BLASCO: Los judíos del reino de Aragón: Balance de los estudios realizados y perspectivas (cit). en la nota 1), \$1.2.2.2 (nota 36).

90 Próximamente saldrá a la luż una nueva aportación sobre el tema de Encarnación MARIN PADilla que lleva por título: Relación judeoconversa durante la segunda mitad del siglo xv en Aragón: Oración. Sobre la expresividad de los conversos aragoneses registrada en procesos inquisitoriales de los últimos años del siglo xv, véase el estudio de VILA RubIO, M. ${ }^{a}$ Nieves, «Notas sobre la expresión de la subjetividad y la afectividad en conversos aragoneses del siglo XV», en I Col.loqui d'Història dels jueus a la Corona d'Aragó. Lleida, Institut d'Estudis Ilerdencs, 1991, págs. 303-312.

gi Lourie, Elena, Crusade and Colonisation. Muslims, Christians and Jews under Crown of Aragon (cit. en la nota 19).

92 GUTWIRTH, Hispano-Jewish Attitudes to the Moors in the Fifteenth Centur, (cit. en la nota 17), págs. 237-262.

${ }_{93}$ LEDESMA, La incidencia del problema judio en las comunidades mudéjares en Aragón (cit. en la nota 23). 


\section{POSIBILIDADES PARA EL FUTURO}

De la misma manera que el hablar de perspectivas lleva implícito hacer referencia al estado de la cuestión, al referirse a lo que se ha hecho, o mejor a lo que se está haciendo, parece oportuno apuntar, aunque sea a grandes rasgos, lo que todavía queda por hacer en determinados campos.

Para no interferir con Romano, no hablaré de demografía, hábitats, impuestos, actividades socioeconómicas ni de lo que se puede hacer para desterrar tópicos y errores antijudíos relacionados con el préstamo (crédito, usura), la facilidad de lenguas, la dedicación a la agricultura, etc. Me limitaré a centrar mi atención en otros aspectos, en cierta manera olvidados o "no explotados", en los que se puede profundizar utilizando los fondos de los archivos aragoneses y los Responsa.

\subsection{Fuentes}

De cuanto se ha dicho, salta a la vista que en los últimos años el interés de los investigadores aragoneses se ha centrado preferentemente en el estudio de las fuentes locales. Por su parte, varios estudiosos israelíes han dirigido su atención preferentemente hacia los Responsa, complemento esencial de la documentación cristiana.

De cara a los nuevos tiempos, parece aconsejable mantener estas líneas, pero además se impone realizar una investigación sistemática y exhaustiva de las fuentes estatales y no estaría de más iniciar otras tantas prospecciones en los archivos privados, principalmente en los nobiliarios y eclesiásticos.

\subsection{Estudios generales: conversos, Inquisición, expulsión}

Mientras no se demuestre lo contrario, las líneas generales de la Historia de los judíos de Aragón que en su día trazara Baer permanecen inamovibles, especialmente para los siglos XII-XIV.

De acuerdo con las premisas apuntadas en el apartado 1.2. al hablar de los estudios sobre la historia de los judíos aragoneses en la Alta Edad Media, no serían justificables ni aconsejables nuevas interpretaciones o elucubraciones sobre materiales archiconocidos y estudiados. En cambio, existe la posibilidad, desde mi punto de vista no sólo acertada sino recomendable, de hacer una recopilación exhaustiva y ordenada de todo el material documental sobre los judíos que se conserva para ese período. 
La escasez de fuentes locales de los siglos XIII y XIV exige que se intensifique la consulta sistemática de los fondos estatales de esos dos siglos, que para este periodo son especialmente abundantes y muy ricas. Asimismo, es preciso rehacer la historia de los judíos de Aragón en el siglo $\mathrm{xV}$, descuidada por Baer especialmente bajo el reinado de Alfonso el Magnánimo, cuando la vida en las aljamas languidece como consecuencia de las numerosas conversiones registradas a raíz del adoctrinamiento de Tortosa y la bula del antipapa Benedicto XIII.

Sin minimizar la importancia al 92, porque la tiene, considero que es preciso retrotraer la atención a dos acontecimientos trascendentales para la historia del judaísmo hispano (los alborotos de 1391 y el adoctrinamiento de Tortosa de 1413-1414) y abordar el estudio de estos hechos con documentos, crónicas y toda clase de información fiable, buscando listas de conversos y, en su defecto, confeccionándolas con los datos que aporta la documentación, para de una vez por todas conocer no sólo el número - un mínimo- de los conversos en los años decisivos (para muchos judios de la Península, 1391; para los judíos del reino de Aragón, 1413-1414) sino también los nombres de los que se convirtieron, aprovechando los datos que los documentos facilitan, pues son mucho más precisos que otras informaciones de tipo literario utilizados hasta ahora ${ }^{94}$. Sólo así podremos conocer el alcance real que estos dos hechos tuvieron para los judíos aragoneses y establecer las verdaderas genealogías de los conversos.

Para calibrar la incidencia real del problema converso y no caer en el error de atribuir al convertido lo que en realidad corresponde a sus homónimos cristianos y viceversa, es preciso seguir la pista de cada uno de los judíos bautizados, especialmente en el período inmediatamente posterior a su conversión, y determinar sus relaciones de parentesco y su posición social. La tarea no es trivial, pues transcurrido un tiempo se silencia el nombre judío, y poco después incluso se omite su condición de converso o neófito. Creo que va siendo hora de ajustar las cifras y de reservar el calificativo «converso" a quien de veras le corresponde, sin dejarse llevar por la intuición, como en ocasiones se ha hecho.

En cuanto al nombre de familia adoptada tras la conversión, interesa destacar la ausencia, al menos aparente, de reglas fijas: algunos apelli-

94 Por ejemplo el Libro Verde de Aragón, texto publicado por Isidro de las Cagigas, Compañía lberoamericana de Publicaciones, Madrid 1929. Véase cuanto dije al respecto en BLASco MARTINEZ, Asunción, Aportaciones documentales para el estudio del origen troncal de los Santángel, "Congreso Internacional «Lluis de Santángel i el seu temps», Valencia 6-8 de octubre de 1987 (su publicación es inminente). 
dos (como Santángel) fueron asignados a familias diversas de judeoconversos ${ }^{95}$; en cambio, hubo miembros de una misma familia que, tras la conversión, tomaron apellidos diferentes; buen ejemplo de ello son los hermanos Abnarrabí, de Zaragoza: mientras que Vidal y Mossé recibieron el apellido Aymerich, Bonafós se hacía llamar Martín García de Salazar y un cuarto hermano, cuyo nombre judío no he consegudio averiguar, respondía a la denominación de Dionís de Castro ${ }^{96}$. Los judeoconversos únicamente mantuvieron el nombre familiar judío cuando tenía, o podía tener, connotaciones cristianas: entre los más conocidos, figuran los Caballería (o Cavallería) y los Trigo ${ }^{97}$.

Para profundizar en el tema de los conversos hay documentos que ofrecen una información de primera mano: los testamentos (tanto de judíos como de conversos), las reclamaciones de herencia o de dote, las concesiones de libelo de repudio, la reivindicación de patria potestad, la venta de asientos de la sinagoga, la venta de libros en hebreo y, en fin, diversos documentos sobre asuntos económicos. Se considera imprescindible revisar con detenimiento toda la documentación emitida tanto por judíos como por cristianos, pues a veces, en los lugares más insospechados, se incluyen veladas alusiones a familiares de otra religión que pueden ser totalmente esclarecedoras.

Dentro del apartado dedicado a los conversos, considero de gran interés estudiar la reacción de la mujer judía ante la conversión, primero, y ante la Inquisición, después, pero con cifras, para ver si procede seguir manteniendo la teoría - no digo que sea tópico- de la firmeza de la mujer judía frente a la debilidad del varón. Y puestos a plantear posibles vías de investigación, tampoco estaría de más averiguar hasta dónde llega la patria potestad del converso en la práctica ${ }^{98}$.

\subsection{Comunidades locales y urbanismo}

La importancia de las fuente locales para la reconstrucción de la historia interna es evidente, según se ha puesto de relieve en una serie de

\footnotetext{
95 Ibidem.

96 Cabezudo Astrain, Jose, “La expulsión de los judíos zaragozanos», Sefarad, XV (1955), pág. 111.

97 Jaime Martínez Trigo, cirujano converso y habitante en Zaragoza, era hijo de Junez Trigo y de Mira Albala, y hermano de Jehudá Trigo. Archivo Histórico de Protocolos de Zaragoza, notario García Gavín, 1421.1.29.

${ }_{98}$ Pienso en la reclamación de patria potestad presentada por una converso zaragozano, con pleno éxito, en 1407, Blasco, El impacto de los ataques de $1391 \mathrm{y}$ del adoctrinamiento de Tortosa en la sociedad judía aragonesa (cit. en la nota 42), $\$ 2.6 .2$, nota 73 .
} 
trabajos monográficos de reciente publicación. Pero no basta centrar la atención en las aljamas aragonesas en la segunda mitad del siglo $\mathrm{xV}$, es decir, cuando la mayoría de ellas atravesaba un período de declive mientras que otras habían desaparecido. Es preciso, además, estudiar la situación de las comunidades judías aragonesas, tanto de realengo como de señorío, en los siglos anteriores, y para eso no queda más remedio que revisar concienzudamente los fondos del Archivo de la Corona de Aragón.

Considero extremadamente arriesgado afirmar que un resto arqueológico es judío si no presenta inscripciones en hebreo o se hallado «in situ» una inscripción en caracteres hebreos. Por eso, me adhiero a la propuesta formulada en diversos foros por Romano para que se realicen excavaciones sistemáticas en el emplazamiento de los cementerios judíos aragoneses $^{99}$.

\subsection{Sociedad e instituciones sociobenéficas}

Siguiendo el modelo de Zaragoza, interesa ampliar el conocimiento de las instituciones sociobenéficas de otras aljamas aragonesas. Dentro de este mismo apartado, convendría centrar la atención en torno a la salud pública, atendida preferentemente en los hospitales que se distribuían por las juderías gracias a su adscripción a una cofradía o al patrocinio de un particular: en ellos se prestaba ayuda a los enfermos, a los que carecían de hogar propio y a los forasteros. El tema de la sanidad judía sigue siendo un enigma para la mayor parte de los aljamas del Reino, y eso que tanto la documentación oficial como la privada suele registrar datos relativos a este asunto.

\subsection{Cuestiones judiciales y derecho}

De acuerdo con lo expuesto en el apartado 1.5, es de esperar que, en tanto aparecen nuevos documentos relacionados con el procedimiento judicial de los tribunales judíos, nuestros colegas conocedores de la lengua y el derecho hebreo contribuyan a suplir las lagunas de la documentación cristiana con la információn que acerca de estas materias han quedado registradas en los Responsa rabínicos.

\footnotetext{
99 Romano, Perspectivas de la Historia judía de la corona de Aragón (cit. en la nota 2), §
} 
Interesa conocer cuándo y cómo aparece la institución notarial entre los judíos, hasta dónde llegan las competencias de los notarios judíos y hasta qué punto dependen de los monarcas cristianos. Como los primeros nombramientos reales de notarios judíos se producen a finales del siglo XIV y comienzos del $\mathrm{XV}$, es imprescindible investigar en las fuentes estatales en torno a estas fechas. La tarea puede resultar en ocasiones ingrata, pues los documentos de estas características no son demasiado frecuentes.

La recopilación y publicación de las actas de cortes del reino de Aragón se inició en el Departamento de Historia Medieval de la Universidad de Zaragoza en tiempo de José M. ${ }^{a}$ Lacarra y dio frutos. Confiamos en que ese proyecto se reanude como paso previo para poder llevar a cabo trabajos similares a los que se han realizado para el reino de Castilla ${ }^{100}$.

Hemos visto $(\$ 1.5)$ que a veces los judíos aragoneses, acogiéndose a privilegios locales, eludieron algunas disposiciones de la ley judía. Considero prioritario determinar hasta qué punto los judíos aragoneses cumplían su Ley, y eso sólo será posible si, con casos prácticos, logramos dar respuesta a una serie de cuestiones teóricas: irealmente no heredaban las hijas?, ¿hasta qué punto se podía desheredar al legítimo heredero?, ¿qué pasaba con los hijos pródigos?

Aparte de cuanto se ha dicho en el $\S 1.5$, existen otros aspectos del derecho que todavía esperan la atención del investigador. Uno de ellos es el de los testigos. Aunque la Ley judía exige la presencia de tres prohombres judíos para que una testificación tenga valor ${ }^{101}$, en los asuntos llevados por los judíos ante los tribunales cristianos las exigencias son otras: así, en los actos entre judío y cristiano interviene un testigo por cada una de las partes, es decir, un judío y un cristiano; si se trata de contratos entre gentes de las tres religiones, los testigos suelen ser tres: un cristiano, un judío y un musulmán; pero cuando los otorgantes son judíos, tiene que haber al menos un testigo cristiano: sea un judío y un cristiano o dos judíos y un cristiano. Los casos en que sólo hay testigos cristianos son excepcionales, y convendría estudiar a fondo esta cuestión, comparando la costumbre del reino de Aragón con lo que sucede en otros estados de la Corona.

Asimismo, sería interesante determinar cuándo comienza la mayoría de edad legal de los judíos aragoneses, tanto en los varones, como en las

\footnotetext{
100 Véanse los artículos de Pilar León, Romano y Monsalvo citados en la nota 76.

101 Regne, Jeant, History of the Jews in Aragon. Regesta and Documents 1213-1327, Ed. and annotated by Yom Tov Assis (Jerusalem 1988), n. 1898 (Barcelona, 1297/98, febrero 26).
} 
mujeres, pues aunque se considera que la bar miswá debe tener lugar a los 13 años, parece ser que la mayoría legal se establece a los $14^{102}$.

\subsection{Vida privada: judios y conversos}

Si exceptuamos los procesos inquisitoriales de finales del siglo xv, no es mucho lo que se dice en la documentación cristiana acerca de la alimentación de los judíos. Considero que los esfuerzos en esta dirección pueden dar frutos -a veces se encuentra un documento maravilloso ${ }^{103}$, pero no es lo más común.

En cuanto al estudio de las familias judías francas, considero que hay que seguir por el camino iniciado, tratando de reunir toda la documentación posible acerca de los Alazar y los Caballería de Zaragoza para paliar los muchos interrogantes que el tema plantea. Puesto que también existen linajes que gozan de franquicia en Calatalyud y Huesca, sería de interés abordar el estudio de las familias francas afincadas en estas dos ciudades.

Acerca de la forma de expresión empleada por los judíos aragoneses, se sabe que escribían la lengua del estado (el aragonés) con caracteres hebreos ${ }^{104}$. Sería interesante llegar a conocer qué lengua hablaban: seguramente sería el romance, pero a falta de documentos sonoros que lo confirmen, la clave puede estar en esas breves anotaciones que a veces se encuentran intercaladas en documentos latinos o romances, o en los márgenes. Con la intención de profundizar en este tema, he recogido más de doscientas firmas de judíos zaragozanos de finales del siglo xIV y comienzos del $x v$, en caracteres hebreos, que a veces incluyen frases o incluso datos relacionados con los autores de la rúbrica. La importancia de las suscripciones es manifiesta: posiblemente permitirán conocer el grado de alfabetización de los habitantes de la judería zaragozana y los tipos de escritura empleados por individuos de diferente estamento social, pues no escribía igual un miembro de la familia Caballería que un arte-

102 Quizás algunos aspectos del derecho judío aragonés se clarifiquen cuando Motis concluya la tesis sobre «Derecho privado y público en las aljamas judías de Aragón en los siglos XIV y XV”.

${ }_{103}$ Buen ejemplo de ello es un hallazgo que me permitió realizar un breve estudio sobre la alimentación de los judios de Barcelona (BLASCO MARTINEZ, Asunción, «El horno del call de Barcelona en 1335\%, Ir Col-loqui d'Història de l'alimentació a la Corona d'Aragó, celebrado en Lérida los días 7-9 de noviembre de 1990).

104 GUTWIRTH, Hispano-Jewish Attitudes to the Moors in the Fifteenth Century (cit. en la nota 17), págs. 293 y ss. 
sano. Las firmas autógrafas permitirán fijar grafías e identificar individuos, pues a veces una misma persona recibe dos nombres y dos apellidos diferentes: el hebreo y el cristiano. No podemos descartar la posibilidad de que entre esas rúbricas aparezca la de un personaje importante: además de Hasday Crescas, en esos años residieron en Zaragoza otros judíos ilustres, como el poeta Salomón de Piera o el calígrafo Vidal (ben) Saúl Satorre, copista de hermosos manuscritos hebreos ${ }^{105}$, etc.

\section{EPILOGO}

He procurado ofrecer una panorámica sucinta de la historia de los judíos de Aragón hoy y sugerir algunos aspectos susceptibles de estudio en un futuro próximo. Como a pesar del esfuerzo realizado puede haber omitido nombres o datos de interés, quisiera disculparme por ello y solicitar la colaboración de todos para subsanar estas omisiones involuntarias. Estoy segura de que esa ayuda potenciará el mejor conocimiento de la historiografía aragonesa actual.

105 Blasco, Asunción; Romano, David, «Vidal (ben) Saúl Satorre, copista hebreo (13831411) , Sefarad, LI (1991), págs. 3-11. 